\title{
The Psychological Well-Being among Government and Non Government School Teachers: A Comparative Study
}

\author{
Kiran Vaghela*
}

\section{ABSTRACT:}

Aim of the research is to find out the Psychological Well-being among School teachers. So investigator selected two groups one is government school teachers and other is non government school teachers, both groups have 400 persons. In one group has 200 and other one groups has 200 persons. The all subjects were randomly selected. Data were collected from Ahmadabad district. Scale was use for data collection is personal datasheet and Psychological Well-being scale developed by Bhogale and Prakash (1995), and data were analysis by "f" test. Result show, There is no significant difference between the psychological well-being of government and non government school teachers. There is no significant difference between the psychological well-being of male and female and urban and rural area.

Keywords: Well-Being, Government and Non Government School Teachers

\section{INTRODUCTION}

From time immemorial teaching has been considered a noble profession. According to Madam Montessori. "The teacher is an active observer and supervisor of children who directs and guides wherever and whenever necessary" But teacher should be effective because it is generally believed effective teacher are the effective instrument for developing effective human resources in terms of student growth in desirable direction cartographer by the guardians of the society and planned by the movement policy-makers. Though the term 'effectiveness' is used frequently in numerous defined formal context such as Organization Administration industry, School University etc. or in informal setting like family. The contemporary literature has avoided to define it because of its inherent ambiguity and complexity. The confusion still persists with regard to the word teaching effectiveness or teacher effectiveness and hence commonly agreed upon criteria of effectiveness are difficult to find. The defining teacher effectiveness two trends are discernible. The first is concerned with student growth-acquisition of ultimate and proximate goals exhibited through their knowledge communication skills and attitudes Second is related to the handling the process variables involved in teaching. Such as, presenting, asking responding, providing feedback, etc Thus teacher effectiveness involves multiple criterion, though the central idea is the integration of personal needs, roles, functions goals and also organizational goals,

*Ph.D Student, Dept. of Psychology, Sardar Patel University, Vallabh Vidhyanagar, Gujarat

(C) 2014, K Vaghela; licensee IJIP. This is an Open Access Research distributed under the terms of the Creative Commons Attribution License (http://creativecommons.org/licenses/by/2.0), which permits unrestricted use, distribution, and reproduction in any Medium, provided the original work is properly cited. 


\section{The Psychological Well-Being among Government and Non Government School Teachers: A Comparative Study}

In psychology to occur many research for to get information about human behaviour in deeply. But is very insufficient research doing on work value, burnout and psychological wellbeing its effect on human behaviour. Psychological well-being indicated physical and mental wellness. Sinha (1990) has stated that Psychological well-being is difficult to define. It has been taken to consist of discomfort or desirability and from any disturbance if mental function. It is a somewhat malleable concept which has to do with people's feeling about everyday life activities. Such feeling may range from negative mental state or Psychological strains such an anxiety, depression, frustration, Emotional, exhaustion, unhappiness, dissatisfaction to a state which has been identified as positive mental healthy [Johada 1958, Warr 1978]

"A state of complete physical mental and social well-being and does not consist only of the obsess of disease of infirmity" -World health organization (WHO) (1948)

"Psychological well-being as the general experience by individual that there will be positive outcome or circumstance" Adams, Bezner, \& Steinhardt (1997)

What war the phase of illness the good of caregivers is to proponent Psychological well-being as "seeking a sense of control in the face of the life threading illness he characterized by emotional distress altered life priorities and fear of the unknown as well as positive life changes" in order on promote Psychological well-being Scanlon suggest that three question be a asked.

1. What do they worry about?

2. How do they cope?

3. How can nurses help?

At the most basic have Psychological well-being (PWD) is quite similar to other term that refer to positive mental status, such as happiness for satisfaction and in many base it is not necessary for helpful to worry about find distinctions between such terms.

Ivan Robertson cooper

The concept of well-being originated from Positive Psychology. The shift from negative to positive psychology is a welcome change in the discipline. The focus of positive psychology is to study the improvement in the lives of individuals. Positive Psychology has emerged from the problem of the west. Thus it may be inferred that knowledge is culturally conditioned.

Well-being is often defined as a sound economic disposition. A western study of relationship between having money, and life satisfaction revealed that between $1940^{\text {ee }}$ s and the year 2000, people needed more money to maintain, the same level of satisfaction. In other words one needed more money to stay happy in 2000 than in $1940^{\circ e} \mathrm{~s}$, with the requirement of money steadily increasing over the years. Another study proved that while the richest American measured 5.8 on satisfaction while the Slum dwellers of Kolkata measured 2.9 indicating again that satisfaction is not directly related to money per se. However, up to the income level of $\$$ 10,000 a correlation between money and satisfaction was found, beyond which addition in 
income did not contribute to well being. Thus an economic criterion was found to have a limitation in predicting well being.

\section{AIMS OF THE STUDY:}

1) To study of the Psychological well-being among government and non government school teachers.

2) To study of the Psychological well-being among male and female.

3) To study of the Psychological well-being among urban and rural area.

\section{HYPOTHESIS:}

1. There is no difference between Psychological well-being of government and non government school teachers.

2. There is no difference between Psychological well-being of male and female.

3. There is no difference between Psychological well-being of urban and rural areas school teachers.

4. There is no interaction effect of Psychological well-being on types of school and sex.

5. There is no interaction effect of Psychological well-being on types of school and types of areas.

6. There is no interaction effect of Psychological well-being on sex and types of areas.

7. There is no interaction effect of Psychological well-being on types of school, sex and types of areas.

\section{METHODOLOGY:}

\section{Research design:}

This research will be adopted $2 \times 2 \times 3$ factorial design as well as 1 is type of School(Government and Non government), 2 is type of sex (Male and female) 3 is types of area(urban and rural).

\section{$2 \times 2 \times 2$ Factorial Design}

$\mathrm{N}=400$

\begin{tabular}{|l|l|l|l|l|}
\hline \multirow{2}{*}{} & \multicolumn{2}{|l|}{$\begin{array}{l}\text { Government School } \\
\text { Teachers (A1) }\end{array}$} & \multicolumn{2}{l|}{$\begin{array}{l}\text { Non government school } \\
\text { Teachers (A2) }\end{array}$} \\
\cline { 2 - 5 } & $\begin{array}{l}\text { Male } \\
\text { B1 }\end{array}$ & Female B2 & Male B1 & Female B2 \\
\hline $\begin{array}{l}\text { Urban } \\
\text { (C1) }\end{array}$ & 50 & 50 & 50 & 50 \\
\hline $\begin{array}{l}\text { Rural } \\
\text { (C2) }\end{array}$ & 50 & 50 & 50 & 50 \\
\hline
\end{tabular}




\section{Sample:}

In this research study of government and non government school teachers shall be selected from Ahmadabad city and there rural areas. This sample will selected by random sampling method. A total of 400 teachers shall be selected. Out of which 200 would be government school teachers and 200 non government school teachers. Out of which 100 would be male and 100 female. From each of this 50 urban area school teachers and 50 rural area school teacher would taken.

Tools used: The following tools were used in the present study:

\section{Psychological Well-being scale:}

Psychological well-being questionnaire developed by Bhogale and Prakash (1995), was used to measure psychological well-being. These are 28 sentences in this scale. All at the sentence had a two option "yes" or "no" belong two option can choose one option and marked by symbol (v). In positive sentence 1 point for yes and 0 point for no. and in negative sentence 1 point for no and 0 point for yes. The test - retest reliability coefficient is 0.72 and internal consistency coefficient is 0.84 . The author has reported satisfactory validity of the questionnaire.

Statistical Analysis: In this study „ffe test was used for statistical analysis. 


\section{RESULT AND DISCUSSION:}

\section{Psychological well being with reference type of school, sex and types of area}

The main objective was to study whether types of school(government and nongovernment), sex(male and female), and types of area(urban and rural) differ in psychological wellbeing. In this context, 7 null hypotheses were constructed. For this purpose $2 \times 2 \times 2$ factorial design was framed. To examine these null hypothesis statistical techniques of two way ANOVA was used. The results obtained are presented in table 1,2, and 3 .

Table no 1 (N=400) Means and SD of Psychological wellbeing with reference type of school, sex and types of area

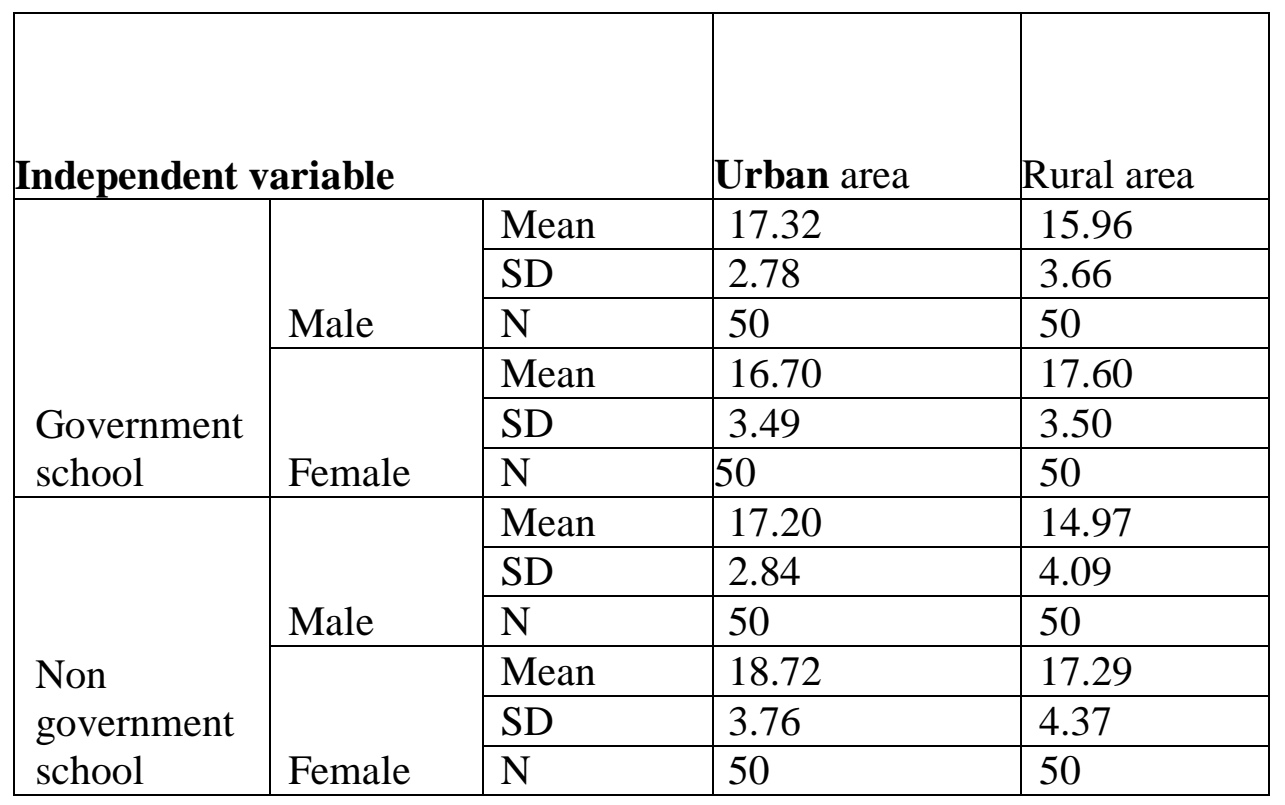


Table no.2 (N=400) ANOVA summary of Psychological wellbeing with reference type of school, sex and types of area.

\begin{tabular}{|c|c|c|c|c|c|}
\hline Source of variance & $\begin{array}{l}\text { Sum } \\
\text { of } \\
\text { squares }\end{array}$ & df & $\begin{array}{l}\text { Mean } \\
\text { Sum of } \\
\text { squares }\end{array}$ & $\mathbf{f}$ & $\begin{array}{l}\text { Sign. } \\
\text { Level }\end{array}$ \\
\hline Type of school & 2.354 & 1 & 2.354 & 0.181 & NS \\
\hline Types of sex & 147.27 & 1 & 147.27 & 11.340 & 0.01 \\
\hline Types of area & 105.375 & 1 & 105.375 & 8.114 & 0.01 \\
\hline Type of school $x$ types of sex & 49.505 & 1 & 49.505 & 3.812 & NS \\
\hline Type of school $x$ Types of area & 63.446 & 1 & 63.446 & 4.885 & 0.01 \\
\hline Types of sex $x$ Types of area & 58.307 & 1 & 58.307 & 4.490 & 0.01 \\
\hline $\begin{array}{l}\text { Type of school x Types of sex } x \\
\text { Types of area }\end{array}$ & 13.421 & 1 & 13.421 & 1.033 & NS \\
\hline SSW (Error) & 5090.94 & 392 & 12.98 & & \\
\hline SST & 120821.00 & 400 & & & \\
\hline
\end{tabular}

Table no. 3, (N=400) Difference between mean score of Psychological wellbeing with reference type of school, types of sex and types of area.

\begin{tabular}{|c|c|c|c|}
\hline Independent variable & $\mathrm{N}$ & Mean (M) & $\begin{array}{l}\text { Difference } \\
\text { between mean }\end{array}$ \\
\hline Government school(A1) & 200 & 16.8950 & $0.165(\mathrm{~A} 1 \times \mathrm{x} 2)$ \\
\hline Non government School(A2) & 200 & 17.06 & \\
\hline Male(B1) & 200 & 16.3719 & $1.2052(\mathrm{~B} 1 \times \mathrm{B} 2)$ \\
\hline Female(B2) & 200 & 17.5771 & \\
\hline Urban (C1) & 200 & 17.48 & $1.01(\mathrm{C} 1 \times \mathrm{C} 2)$ \\
\hline Rural(C2) & 200 & 16.47 & \\
\hline
\end{tabular}

Psychological wellbeing with reference to type of school:-

When $\mathrm{f}$ test was applied to check the impact of Psychological wellbeing on type of school, significant $\mathrm{f}$ value was found. The $\mathrm{f}$ value (table no.2) is 0.181 which are statistically no significant. Table no.3 reveals that the mean scores of Psychological wellbeing of Government and Non government school are 16.8950 and 17.6 respectively Hence the null hypothesis 1 was maintained and it was concluded that there was no significant impact and the difference between two is 0.165 which is very low and negligible. of psychological wellbeing on Government and 


\section{The Psychological Well-Being among Government and Non Government School Teachers: A Comparative Study}

non government school teacher.

\section{Psychological well being with reference to sex :-}

When $f$ test was applied to check the impact of psychological wellbeing on types of sex, significant $f$ value was found. The $f$ value (table no.2) is 11.34 which are statistically significant on level 0.01. Table no.3 reveals that the mean score of psychological wellbeing of male and Female are 16.3719 and 17.5771 respectively and the difference between two is 1.2052 which is very high and not negligible. Hence the null hypothesis 2 was rejected and it was conclude that there was significant impact of psychological wellbeing on male and female.

Psychological well being with reference to types of area:-

When $f$ test was applied to check the impact of psychological wellbeing on types of area, significant $\mathrm{f}$ value was found. The $\mathrm{f}$ value (table no.2) is 8.114 which is statistically significant on level 0.01 . Table no.3 reveals that the mean scores of psychological wellbeing of area are 17.4850 and 16.47 respectively and the difference between two is $1.01(\mathrm{C} 1 \times \mathrm{C} 2)$, which is very high and not negligible. Hence the null hypothesis 3 was rejected and it was concluded that there was significant impact of psychological wellbeing on urban and rural area.

\section{Psychological wellbeing with reference to interaction effect of type of school and sex :-}

When $\mathrm{f}$ test was applied to check the interaction effect of psychological well being on type of school and sex, no significant interaction effect was found. The F value (table no.2) is 3.81 which are statistically not significant. Hence the null hypothesis 4 was maintained and it was conclude that there was no significant interaction effect of psychological wellbeing on type of school and types of sex.

\section{Psychological wellbeing with reference to interaction effect of type of school and Types of area:-}

When $\mathrm{f}$ test was applied to check the interaction effect of psychological well being on type of school and types of area, significant interaction effect was found. The f value (table no.2) is 4.885 which is statistically significant. Hence the null hypothesis 5 was rejected and it was conclude that there was significant interaction effect of psychological well being on type of school and types of area.

Psychological wellbeing with reference to interaction effect of sex and types of area.:When $f$ test was applied to check the interaction effect of psychological well being on sex and types of area, significant $\mathrm{f}$ value was found. The $\mathrm{f}$ value (table no.2) is 4.49 which are statistically significant on level 0.01 . Hence the null hypothesis 6 was rejected and it was concluded that there was significant interaction effect of sex and types of area. 


\section{The Psychological Well-Being among Government and Non Government School Teachers: A Comparative Study}

\section{Psychological wellbeing with reference to interaction effect of type of school, sex and types of area:-}

When $\mathrm{f}$ test was applied to check the interaction effect of type of school, sex and types of area, significant $\mathrm{f}$ value was found. The $\mathrm{f}$ value (table no.2) is 1.033 which are statistically no significant. Hence the null hypothesis 7 was maintained and it was concluded that there was no significant interaction effect of type of school, types of sex and types of area.

\section{CONCLUSION:}

1. There is no significant difference between Psychological well-being of government and non government school teachers.

2. There is significant difference between Psychological well-being of male and female.

3. There is significant difference between Psychological well-being of urban and rural areas school teachers.

4. There is no significant interaction effect of Psychological well-being on types of school and sex.

5. There is significant interaction effect of Psychological well-being on types of school and types of areas.

6. There is significant interaction effect of Psychological well-being on sex and types of areas.

7. There is no significant interaction effect of Psychological well-being on types of school, sex and types of areas.

\section{REFERENCES:}

1. Bhogle and Prakash (1995). manual of the psychological well-being questionnaire.

2. Broota, K. D., (1992), Experimental design in behavioral research, Wiley, Veastern Limited.

3. Campbell, A., (1980), The sense of well-being in America, New York: Mc Graw Hill.

4. Jahoda, M. (1958), current concept of positive mental health. Newyork: basic book.

5. Singh, D., (1990), Concept of psychological well-being : Western and Indian perspectives,

6. NIMHANS Journal, Vol. 8, pp. 1-11.

7. Suvera, P.S., (2001), Religious behavior, death anxiety and psychological well-being : A comparative study of institutionalized and non-institutionalized aged, unpublished M.Phil Thesis, Saurashtra University, Rajkot.

8. Warr, P.B., (1978), A study of psychological well-being, British Journal of Psychology, Vol. 69. 